\title{
The Readiness of the Community in Developing the Panji Anom Village Area as a Sport Tourist Destination
}

\author{
$1^{\text {st }}$ Danardani, Wasti \\ Sports And Health Faculty \\ Ganesha University Of Education \\ Buleleng, Indonesia \\ wastidani@gmail.com
}

\author{
$2^{\text {nd }}$ Hidayat, Syarif \\ Sports And Health Faculty \\ Ganesha University Of Education \\ Buleleng, Indonesia \\ syarif.hidayat@undiksha.ac.id
}

\begin{abstract}
The economic level of Panji Anom village is still low, the government says it is impossible to survive in the agricultural sector. The purpose of this study was to see the readiness of the Panji Anom village community, Sukasada District, Buleleng Regency in developing the village as a special interest tourism destination (sports tourism). This is a qualitative research. The research method used in this research is a survey aimed at the people of Panji Anom Village. The survey will be carried out by means of a questionnaire and through observation to get a portrait of the potential of the village. The subjects used were taken randomly with criteria limitations so that they could represent all levels of society. The results showed that the environment has attractive potential, people are willing to open themselves up to develop the area into a tourist destination, but there is still a need to prepare skilled workers from the local community as tourism workers.
\end{abstract}

Keywords- Readiness, Community, Sport Tourist.

\section{INTRODUCTION}

The Buleleng Regency Government is trying to develop the northern Bali region as a tourism destination. Regional development as a tourist destination is not an ambition to increase the goals of Buleleng Regency on its own. Furthermore, the vision of this program is to improve the economic level of the Buleleng community. One of the concerns of the Buleleng Regency government is the watershed area in Sukasada District. Panji Anom Village is one of the villages that intersect with the watershed in Sukasada District.

Involving the community is what must be done to make Panji Anom Village a tourist area. Involving the community is one step towards improving the village economy. ${ }^{[1]}$ revealed that the role of society in making decisions is an important role in carrying out further development. So involving the community is an obligation.

The tourism object that will be developed in the village of Panji Anom is a special interest in sports tourism. Selling the natural and cultural wealth of villagers as an experience. Enjoy this experience through sports activities in the village by visiting interesting locations. The tourism activities that will be held in the village of Panji Anom are an unusual activity. Only tourists with an interest will join this tour. The problem in this research is to see the readiness of the community in developing the area as a tourist destination.

The purpose of this research is to see the readiness of the community in developing sports tourism. The readiness of the community to become tour guides and sports tourism organizers is the focus of community development. Community involvement is very close to the vision and mission that has been set by the Panji Anom village government, namely improving the people's economy.

\section{METHOD}

This study uses a qualitative grounded theory method. The method of collecting the data of this study through field notes, interview toward the informants by taking a note and recording the information. The information is gained from the stories which have been delivered by the informants, with no treatment involved from the researchers. The technique of collecting the data is done by collecting the documentation, while the narrative note is gained from the subject of the study and narrative interview from the researchers ${ }^{[2]}$. does not provide treatment to the subject. Extracting information through questionnaires distributed to village communities.

The research object is the Panji Anom village community, who are participating in village activities in an activist group. This group involves the village government, group elders and youth groups. Considered sufficiently representative of the Panji Anom village community.

\section{RESULT AND DISCUSSION}

\section{A. Development of village areas by utilizing youth groups}

The demographic bonus is a force that can drive the development of a country. Indonesia is one of the countries that has a demographic bonus in 2030-2040. The demographic bonus is the advantage of the availability of productive human 
resources (15-65 years) which can affect the economy. In fact, this condition will not just happen. It takes careful planning in accordance with the potential of each area. Planning for job opening and development of human resources in accordance with regional potential.

Respondents in this study can describe the condition of society that has a large enough young group. This can be seen from the age group of respondents under 20 yo 8.3\%, 20-29 yo $22.2 \%, 30-39$ yo $19.4 \%, 40-49$ yo $30.6 \%$ and 50 yo and over $19.4 \%$. Looking at the age range of the respondent community, it can be said that the village of Panji Anom has a young group who can be relied on as a driving force for village development.

Panji Anom Village has human resources with productive age. However, it has an average high school education level. However, he does not have special expertise in a certain field, especially in the field of sports tourism or tourism in general. This is illustrated by the foreign language skills of the local community, which indicates that only 8 percent of respondents have passive English proficiency. Young people will be eliminated in era the Industrial 4.0 if they have low education and skills ${ }^{[3]}$. Revealed that formal education levels do not have a problem with human resources in the tourism sector, but are supported by professional training as a support ${ }^{[4]}$. That way, the available youth groups must receive training to improve their skills. The skill in question is the ability of human resources to handle tourism businesses, especially sports tourism.

The level of education, experience, access to information, and the environment are things that support regional economic development in the tourism sector ${ }^{[5]}$. The condition of the Panji Anom village community does not fulfill 2 things, namely the level of education and experience. The development of this area is a new thing, so it is certain that no one has experienced this business.

\section{B. The condition of community on the occasion of village development from sports tourism}

The plan and strategy for the development of the Sukasada sub-district, through the official website of the Sukasada District ${ }^{[6]}$, states economic development through the fields of agriculture, plantation, livestock, tourism and the people's handicraft industry. These five fields will be maximally empowered to improve people's lives. Especially in the tourism sector, the local government explores the potential of the area that can be used as a new tourist attraction. Panji Anom Village is a village that has natural resources that have not been managed. The village government is seriously trying to deal with the development of this area. Through the development of tourism villages by empowering the community, it has implications for the regional socio-cultural resilience in the form of strengthening and several changes in social, cultural and environmental values ${ }^{[7]}$. reinforced ${ }^{[8]}$, which states that the increasing number of tourism visits has an impact on the economy in the region.

This study sees an overview of the level of public knowledge about tourism in general in a good category.
Judging from the results of the questionnaire stating that they understand tourism activities. understand that tourism can bring income for villagers so that it is considered very beneficial for villagers. besides that, they also understand matters relating to tourism management. They even understand the importance of environmental preservation to support their area as a tourist destination.

The rest They also recognize the potential of Panji Anom Village. Panji Anom's natural potential includes waterfalls, rice fields with subaks and village forest areas. the culture of the village community is also interesting as a show or optional activity, including special culinary delights.

The goal of improving the people's economy will not be achieved. If the readiness of tourism objects is available, there is support from the village government and community support without involving the community as the implementing human resource, this will be in vain. reseach finds that the development of an area as a tourist destination will absorb more labor ${ }^{[9]}$. In line with research from ${ }^{[10]}$ conducted in several regions of East Java, it also shows that the stretching of tourism triggers employment. Research conducted in East Kalimantan also shows that tourist destinations absorb more labor and increase the economy compared to hotels and restaurants ${ }^{[11]}$. Bringing in human resources from outside the village will benefit others. The people of Panji Anom village will only be spectators.

\section{Improving the quality of the Panji Anom village community in supporting the development as a sports tourism destination}

The tourism sector is an activity that is directly related between people. Even though in the industrial era 4.0, everything can be replaced with tools / robots, but the goal of a person traveling is to be able to interact with people from other place. In addition, some forms of tourism, such as sports tourism, require more direct tour guides than applications. Some sports tourism carries a high risk, so it requires colleagues who understand and help right away. So that the need for human resources with special sports tourism skills is needed, to maintain the comfort and safety of tourists.

The opinion about the readiness of the community is good, in the village part it is determined as a tourism destination. Actively participate in village development by supporting programs prepared by the village government. The village community prepares to welcome the visiting guests. Meanwhile, guides with basic skills are still lacking. It is seen from the respondents who filled out the questionnaire they level education att $90 \%$ had high school and lower. Do not have skilled personnel in handling this tourism activity.

However, Panji Anom village does not yet have no one tour guide. they will start a tourism business based on nature. a relaxing activity with considerable risk, so the need for a skilled guide is needed. They really need the development of tour guides for the regional development project of Panji Anom village as a tourist destination. Usually, Development of maids in Bali is usually carried out from generation to generation, meaning that from senior guides training to juniors 
${ }^{[12]}$. The same problem was found in the research ${ }^{[13]}$, where training people with special skills was the solution to the problem. The young manpower owned by the Panji Anom village is very possible to develop themselves as tourism workers. Self-development of tourism personnel through the tourism support group, under the auspices of the tourism office and the creative economy. Findings in the research ${ }^{[14]}$, show that human resource development in the tourism sector through training is in accordance with the needs, especially skills through routine training. Sports tourism is an active tourism activity, so it requires reliable personnel.

The unpreparedness of human resources to support the development of the village of Panji Anom is a big problem. However, this can be overcome by holding training in accordance with the needs of a tour guide. Based on the deficiencies revealed in the research, the focus of training is on 1) improving foreign languages, 2) increasing skills as a special interest (sports) guide, and 3) increasing the skills of management personnel.

\section{CONCLUSION}

The village government has planned sports tourism activities in the village of Panji Anom, aimed at improving the economy of the people. The government realizes that villages have locations that can be used as tourist destinations. It's just that the village government is still considering other supporting matters. In this study, it was seen the availability of workers with many productive ages. the village people are enthusiastic about the efforts made by the village government to open the village into a tourist area. However, young people who do not have skills in the field of sports tourism were found to be low in education.

In the future, the availability of tour guides can be carefully prepared to improve services to tourists. Not only tour guides but managerial staff also need to receive training. So that Panji Anom village with its beautiful environment really becomes a reliable alternative tourist destination.

\section{ACKNOWLEDGMENT}

The openness of the people of Panji Anom village to cooperate in conducting this research has a very big role. It is not easy to be able to open up and accept new people from outside the environment. With various kinds of questions, to express curiosity about the potential of Panji Anom village. Until finally this research was completed and became a publication article to introduce Panji Anom village as an area that is ready to develop.

\section{REFERENCES}

[1] Latif, Adam., Irwan., Rusdi, Muhammad., Mustanir, Ahmad., Sutrisno, Muh. 2019. Partisipasi Masyarakat Dalam Pembangunan Infrastruktur D Desa Timoreng Panua Kecamatan Panca Rijang Kabupaten Sidenreng Rappang. Jurnal MODERAT, Volume 5, Nomor 1, Februari 2019, hlm 1 15 ISSN: 2442-3777 (cetak) Website: https://jurnal.unigal.ac.id/index.php/moderat ISSN: 2622-691X (online).

[2] Creswell, John. 2015. Riset Pendidikan, Perencanaan, Pelaksanaan, dan Evaluasi Riset Kualitatif \&Kuantitatif, Edisi Kelima. Yogyakarta Pustaka Pelajar.

[3] Abrar, M., Amalia, N., \& Handoyo, R. D. (2019). Karakteristik dan Peluang Pengangguran Usia Muda di Provinsi Aceh dalam Menghadapi Era Revolusi Industri 4.0. Jurnal Kebijakan Pembangunan, 14(2), 157 169 Retrieved

from http://jkpjournal.com/index.php/menu/article/view/23

[4] Sahras, Hanna. 2019. Mutual Recognition Arrangement dan penyebaran Tenaga Kerja Indonesia di bidang profesional pariwisata dalam era Masyarakat Ekonomi ASEAN http://repository.unpar.ac.id/handle/123456789/8466

[5] Sandria, Nanda Effrinatasya., Tjokropandojo, Dewi Sawitri., Asirin. 2018. Kapasitas Sumber Daya Manusia Dalam Mendukung Pengembangan Ekonomi Lokal Berbasis Pariwisata (Studi Kasus: Desa Pulau Pahawang) Http://Repo.Itera.Ac.Id/Assets/File Upload/SB1811140029/PEG0078 11 124859.Pdf

[6] https://sukasada.bulelengkab.go.id

[7] Andriyani, Anak Agung Istri., Martono, Edhi., Muhamad. 2017. Pemberdayaan Masyarakat Melalui Pengembangan Desa Wisata Dan Implikasinya Terhadap Ketahanan Sosial Budaya Wilayah (Studi Di Desa Wisata Penglipuran Bali). Jurnal Ketahanan Nasional Issn: 0853 9340 (Print), Issn: 2527-9688 (Online) Online Sejak 28 Desember 2015 Di: Http://Jurnal.Ugm.Ac.Id/Jkn Volume 23 No. 1, 27 April 2017 Halaman 1-16.

[8] Mumu, Nifel Elvis., Rotinsulu, Tri Oldy., Engka, Daisy S.M. 2020 Pengaruh Sektor Pariwisata Terhadap Pertumbuhan Ekonomi Dan Penyerapan Tenaga Kerja Di Provinsi Sulawesi Utara. Jurnal Pembangunan Ekonomi Dan Keuangan Daerah. Jurnal Pembangunan Ekonomi Dan Keuangan Daerah. Vol 20, No 5 (2020) $>$ Mumu. https://doi.org/10.35794/jpekd.30046.20.5.2020.

[9] Tradena, Dewi (2017) Pengaruh Industri Pariwisata Terhadap Penyerapan Tenaga Kerja Ditinjau Dari Perspektif Ekonomi Islam Studi pada Hotel dan Biro Perjalanan Wisata Kabupaten Pesisir Barat ). Undergraduate thesis, UIN Raden Intan Lampung. http://repository.radenintan.ac.id/id/eprint/639.

[10] Sanaubar, Ghaniy., Hidayat, Wahyu., Kusuma, Hendra. 2017. Pengaruh Potensi Pariwisata Terhadap Penyerapan Tenaga Kerja Sektor Perhotelan Di 9 Kabupaten/Kota Provinsi Jawa Timur Tahun 2012 2015. Jurnal Ilmu Ekonomi Vol 1, No 3 (2017) $>$ Sanaubar.

[11] Maria, Siti. 2016. Dampak Sektor Pariwisata Terhadap Kesempatan Kerja Pariwisata Di Provinsi Kalimantan Timur. Conference on Management and Behavioral Studies Universitas Tarumanagara, Jakarta, 27 Oktober 2016

[12] Hidayat, Syarif. 2018. Model Pengembangan Pramuwisata Olahraga dalam Bisnis Pariwisata di Provinsi Bali. Jurnal Penjakora. Vol 5, No 1 (2018) $>$ Hidayat

[13] Handayani, S., Fajri, H., \& Pramudia, H. (2018). Pemberdayaan Kelompok Masyarakat Dalam Mengembangkan Olahraga Pariwisata Di Pulau Sirandah Melalui Pelatihan Tenaga Guide Olahraga Pariwisata. Jurnal Stamina, 1(1), 380-390. https://doi.org/10.24036/jst.v1i1.123

[14] Saleh, Mohammad., Diartho, Herman Cahyo., Pratiwi, Ellya Dwi. (2020) Strategi Pengembangan Tenaga Kerja Sub Sektor Pariwisata (Studi Kasus : Pariwisata Kabupaten Pacitan). Volume 21 Jilid 2 No 2 (2020) Jurnal.uns.ac.id/cakra-wisata. Hal 13-23. 